\title{
Community Participation in Tackling Domestic Violence
}

\author{
Syamsul Fatoni* \\ Faculty of Law, University of \\ Trunojoyo Madura \\ E-mail: syamsul.fatoni@trunojoyo.ac.id
}

\author{
Dewi Muti'ah \\ Faculty of Law, University of \\ Trunojoyo Madura \\ E-mail: dewi.congir@gmail.com
}

\author{
Dodik Pranata Wijaya \\ Faculty of Law, University of \\ Trunojoyo Madura \\ E-mail:dodik.p.wijaya@gmail.com
}

\begin{abstract}
The basic principle of the 1945 Constitution as affirmed in Article 3 Paragraph (1) of Law no. 12 of 2011 concerning the Formation of Laws and Regulations is a legal basis in Laws and Regulations so the source of regulations formation under it, especially on tackling cases of domestic violence that result in physical, sexual, psychological suffering and/or family neglect including threats to commit acts, coercion/deprivation of liberty unlawfully in the family. Community participation is an urgent part in addition to the need for support from other criminal justice sub-systems. This study is doctrinal legal research with a statute approach in addition to a conceptual approach. The analysis is conducted qualitatively with a grammatical exegesis and systematically. This research found that Article 1 of Law No. 23 of 2004 concerning the Elimination of Domestic Violence that there is an integrated effort and synergy between the government and society. Specifically, for community participation in preventing domestic violence and providing protection (providing a sense of security to victims of domestic violence), members of society are also expected to be aware of domestic violence cases, thus everyone who hears, sees or knows about a domestic violence case must make efforts in accordance with their limits to: prevent criminal acts; provide protection to victims; provide emergency assistance; assist the process of filing a request for protection (Article 15 of the Domestic Violence Act).
\end{abstract}

\section{Keywords: community participation, women, victims}

\section{INTRODUCTION}

Preferred legal protection must provide a sense of justice for women victims of domestic violence, which in principle is the responsibility of government officials and society. Legal protection for victims of domestic violence is arguably still problematic, especially with regards to provisions in criminal law which require that a criminal act can only be prosecuted if a complaint is made, besides the existence of a crime being considered ordinary.

According to Alan Coffey, as cited by Mardjono Reksodipoetro [1], fragmentation, a situation in which each function works independently and neglects the interrelationship of other segments so that the law of cause and effect applies, must be prevented in the criminal justice system. Likewise, C.G. Howard \& R.S. Mumners's theory is associated with violence against women, which is reflected in Law: Its Nature and Limits [2] as cited by Achmad Ali, that factors that influence "obedience to laws" include: optimal socialization of all targets of the rule of law; sanctions of the rule of law must be suitable because some purposes may not be appropriate to apply to other purposes; severity of sanctions must be proportional and possible to apply, the effectiveness of the rule of law depends on its optimal enforcement and professionalism of officials in the making of laws, socialization, enforcement from legal discovery (the use of legal reasoning, interpretation and construction) and its application to concrete cases, including the participation of the public.

Law enforcement efforts in criminal law cannot be viewed as partially the responsibility of certain parties. This is due to the relationship between various parties in handling it as a system. Therefore, as a system it is necessary to understand the criminal justice system, including the existence of community responsibility in the form of participation.

The key problem of this study is to answer the following question: Why is community participation required to fight domestic violence?

\section{METHODOLOGY}

This study is doctrinal legal research with a statute approach in addition to a conceptual approach.

The type of research is Doctrinal Law Research, which is literature law research conducted by examining secondary data [3] as a process of finding legal rules, legal principles, and legal doctrines to answer legal problems faced to produce new arguments, theories or concepts as prescriptions to solve problems [4].

The analysis is conducted qualitatively with a grammatical exegesis and systematically where an interpretation is done by interpreting the law as part of the entire legal system connecting it logically and systematically with other laws.

\section{RESULT AND DISCUSSION}

A. The Existence of the Convention on the Elimination of All Forms of Discrimination against Women and a Paradigm Shift from Private to Public

In 1992 a UN Committee through the Convention on the Elimination of All Forms of Discrimination against Women (CEDAW) began to emphasize that violence against women was a form of discrimination against women and outlined the foundation on actions needed to be taken by the convention 
participants, governments and citizens of all countries including Indonesia. One key point of the convention stated that the traditional attitude of seeing women as subordinated to men as well as the standardization of gender roles (stereotypes) which in practice continue to develop are associated with violence and coercion that go against women. The effect of violence against women's integrity is the removal of equal enjoyment, the revocation of practice and knowledge of human rights, and the breach of fundamental freedom.

Despite the existence of customary law communities have been set in the constitution of Indonesia, [5] cases of domestic violence have become a hidden crime and few are revealed in the justice court, even though the law for a legal basis has been in place.[6] Law No. 23 of 2004 concerning the Elimination of Domestic Violence (hereinafter referred to as UUPKDRT) outlines several criminal acts of domestic violence as a complaint offense as regulated in Articles 51, 52 , and 53 that due to its private nature it becomes difficult to apply optimally. Adherence to the offense of complaint of this law only strengthens victims' unwillingness to report the violence they experienced because the nature of the offense of complaint can be interpreted to take the male-dominated perpetrators' side.

This creates an image that domestic violence belongs to a private domain that it impacts on law enforcement, including public's reluctance to take preventive measures or legal action. But in its development from a private matter can shift to a public matter, which demands the role of the state and society to protect the rights of citizens from unlawful acts.

\section{B. The Role of Society in Cases of Domestic Violence}

One consideration in Law number 23 of 2004 concerning the Elimination of Domestic Violence states that "Every citizen has the right to have a sense of security and freedom against all forms of violence," which is in accordance with the philosophy of Pancasila and the 1945 Constitution of the Republic of Indonesia.

Most people know about the PKDRT Law, although in detail they do not understand it technically, Law No. 23 of 2004 concerning the Elimination of Domestic Violence (PKDRT) consists of 10 Chapters and 56 Articles. The purpose (Article 4) is to provide protection, prevent violence, preserve family harmony, and to punish perpetrators. The objects of this rule (Article 2) are husband, wife, and children. It also includes family members and domestic workers living in the house.

The basis of protection according to Article $14^{\text {th }}$ of Law No.23 of 2004 is that protection is all efforts aimed at providing security to victims carried out by the family, advocates, social institutions, the police, prosecutors, courts, or other parties that are done temporarily or in line with the court's decision." Temporary protection, as referred to in Article $15^{\text {th }}$, is "protection provided directly by the police and/or social institutions or other parties prior to the issuance of a court order". Meanwhile, Article $16^{\text {th }}$ of this Law states that "a protection order is a stipulation issued by the court to provide protection to victims."

Legal Protection relating to women victims of domestic violence according to Philipus $M$. Hadjon comprises protection facilities, namely: preventive legal protection facilities and repressive legal protection facilities. Preventive legal protection facitilities are a general form legal protection while repressive legal protection facilities in Indonesia are handled by institutions such as courts in the general court ecosystem, government agencies which are administrative appeals and special bodies.[7]

Legal protection for victims (including domestic violence), has been discriminated against by criminal law, for the victims are basically the most disadvantaged parties. Meanwhile, the Indonesian criminal law is offender-oriented, namely the perpetrators of crimes. If it is associated with the development of legal concepts and principles that provide legal bases in the formation of positive law and legal methods with regards to changes in the legal bases following the legal methods, while laws will change in accordance with the development of society, thus it is influenced by time and place.[8]

The rise of domestic violence cases, be it physical, psychological, or sexual and family neglect in society make it necessary to take measures, including prevention and providing protection to victims. Victims oftentimes do not dare to report, partly because of family ties, certain social values, good reputation of the family or herself, or the victims feel worried if the perpetrators take revenge. Difficulties like these are expected to arise if the victims do report.

Article 1 of Law No. 23 of 2004 concerning the Elimination of Domestic Violence) requires an integrated effort and synergy between the government and society. Therefore, to provide services to victims, the national and regional governments, in accordance with their respective functions and duties, can make the following efforts: a. providing a special service room in the police station; $b$. providing apparatuses, health workers, social workers and spiritual mentors; c. creating and developing a system and cooperation mechanisms of service programs involving parties that can be accessed easily by victims; and $\mathrm{d}$. providing protection to victims' companions, witnesses, families and friends. (Article 13 of the UUPKDRT). To realise this, the national and regional governments, in accordance with their respective functions and duties, can work together with society or other social institutions (Article 14 UUPKDRT).

In the context of community participation, socializing, handling and protecting victims of domestic violence is a complex matter. It is inseparable from the culture of our society which tends to be secretive about family problems, making it one of the main obstacle factors. Conversely, others also do not deserve to interfere in other people's internal problems. Ideally, family problems should be resolved by the family itself. But if it fails, legal mechanisms and formal social control can get involved. Domestic violence is categorized as a complaint offense, meaning that only victims (including parents and those authorized) can report an incident to the authorities. However, community members who are aware of a domestic violence case are required to provide protection to victims wherever possible by means of/through certain procedures.

Community participation, by referring to the opinion of von Savigny (1779-1861) with his School of History and Culture that law is an embodiment of public legal awareness (volksgeist) that all laws originate from customs and beliefs rather than from lawmakers, at the same time he opposes the 
decisions of the legislature because they will harm society due to the fact that it is not always in accordance with the legal awareness of the public.[9]

Furthermore, members of society are also expected to be aware of domestic violence cases, thus everyone who hears, sees or knows about a domestic violence case must make efforts in accordance with their limits to: prevent criminal acts; provide protection to victims; provide an emergency assistance; assist the process of filing a request for protection (Article 15 of the Domestic Violence Act). In addition, because this law is a product of lex spesialis in terms of synergy between institutions, hence an active role of NGOs, Neighborhood Association (RT), Residents Association (RW), Head of Village, Head of District, and other government bodies must also be realized. Technically, Law No. 23 of 2004 is concerning the Elimination of Domestic Violence (UUPKDRT)

Public awareness will function as motivation and play a role in tackling domestic violence. Discussion forums and community formation serve to control efforts in combating domestic violence. In this case their neighborhood serves as a place to exchange information should violence occurs in a family within the neighborhood.

Efforts that can be carried out as a form of community participation in overcoming domestic violence include doing socialization to people, especially to social institutions at the RT and RW levels by taking into account the conditions of the community whose violence cases are abundant, through civic organizations such as dasawisma, religious gathering forums/pengajian and asking for help from community leaders) on the importance of a harmonious family, through collaboration with community and religious leaders, and establishing cooperation with the government in increasing community participation to overcome domestic violence. Another effort is to provide training for community and religious leaders who are interested in becoming mediators in preventing domestic violence. In addition, society and social institutions devoting to women and children can establish service posts or safe houses (shelters) for victims of domestic violence.

Community participation in handling domestic violence cases is possible through legal mediation or legal route with some considerations. Resolving cases through legal mediation or outside the court offers the following advantages: (1) reducing congestion of cases in courts; (2) Increasing community participation (legal decentralization); (3) Easing access to justice in society; (4) providing a settlement opportunity acceptable by all parties; (5) settlement of cases is faster and less costly; (6) closed/confidential; (7) the level of agreement is higher, so the relationship between disputing parties in the future will remain firm; (8) Reducing the spread of "dirty games" in courts.[10]

Victims of domestic violence are given the power to report cases to the police (or to the head of an NGO or UPP who will subsequently get it reported to the police) directly, through family members and other people in the victims' houses or in the sites of the cases. Next, 24 hours after a report is submitted, the police (social institutions or other parties) will provide temporary protection before a protection order from the government is issued. In providing temporary protection, the police will cooperate with health workers, social workers, volunteer assistants and/or spiritual mentors to assist victims.

Besides, community participation by utilizing the concept of Restorative Justice as a means to respond to the development of the criminal justice system by emphasizing community and victims' involvement with mechanisms that work in the current criminal justice system. On the other hand, restorative justice is also a new framework that can be used in responding to a criminal offense for law enforcement and officials. Mediation is selected because with it not only a legal certainty is sought but facts are also presented so what is obtained is the truth and what will be decided to solve problems involving two parties can be compromised without any pressure.

Arif Gosita argues that to provide protection to victims, it is necessary to pay attention to victims' rights relating to a case, namely: 1. receiving compensation for their suffering in accordance with the ability to compensate the creator of the victims and the level of involvement/participation/role of the victims in a crime, with such delinquency and deviation; 2. refusing compensation for the benefit of the victim creator (unwilling to be compensated due to it being not needed); 3 . receiving compensation for victims' heirs if the victims die due to the act; 4 . receiving training and rehabilitation; 5. recovering property rights; 6 . receiving protection against threats from the victim creator when reporting and becoming witnesses; 7. receiving assistance from legal advisors; 8. using legal efforts (recht middelen).[11]

Listening to the rampant incidents of domestic violence in society, we cannot just ignore it, it is necessary to take action. However, it turns out that preventing and providing protection for victims of domestic violence is not as simple as the pronunciation because regarding domestic violence is not actually a sensitive matter, so socializing and handling domestic violence ends up being a separate and quite complex and complicated problem. It cannot be denied that our culture, the culture of our society, which tends to be closed about "domestic" problems, internal domestic problems are one of the main factors.

The culture in our society "wants" that the wife can hide or keep her family problems secret from others, so as not to become a family disgrace. On the other hand, it is taboo / inappropriate for other people to interfere in other people's household matters. Ideally, family problems should be resolved by the family itself, but if this does not work, so that the problem becomes widespread and acute, perhaps it is time to involve formal social control mechanisms. Domestic Violence (KDRT) is categorized as a complaint offense, meaning that only the victim (including parents and those given power of attorney) can report this incident to the authorities. However, community members who are aware of the occurrence of domestic violence are obliged to provide protection to victims as much as possible through certain procedures.

In principle, what is regulated in the new PKDRT Law is the starting point for the struggle to form a happy, prosperous family, because the most important thing of all is its implementation, making it happen. The elimination of domestic violence must be fought for. Just waiting for a helping hand from the government is not possible. It takes the care of all of us as citizens of the community to make it 
happen. A law will only become a strand of pearls without meaning, if it is not followed by real efforts to implement it.

As a system, community participation must be supported by the Implementation Tools of the PKDRT Law in the perspective of the Criminal Justice System, including:

a. There must be synergy between the criminal justice subsystem in tackling domestic violence, in addition to the need for support from related parties such as volunteer companions, psychologists, hospitals, safe house service providers (women crisis center),

b. Although there are good intentions from law enforcers to use this new law in handling cases of domestic violence, there are still too many differences in perceptions between law enforcers themselves which result in obstruction of the application of this law. This difference in perception concerns the understanding of the forms of violence and its elements, the scope of "household", the roles and qualifications of victim assistants, the role of the government, the rights to report by the community and the management of the funds to be paid by the perpetrator;

c. The umbrella policies under the law, such as implementing regulations and state budget allocations, are still far from adequate, making it difficult to handle them according to what is mandated in Law no. 23/2004 this. This was especially true in the early stages of treatment, which involved the police, health care institutions and victim assistance;

Cultural constraints are still very big for women victims of domestic violence to carry out the legal process thoroughly, so that many cases are withdrawn after being processed by the police. As a result, the percentage of domestic violence cases that reached the court table was very small compared to the total cases of domestic violence that occurred in the community. Community participation is urgent in tackling domestic violence cases

\section{CONCLUSION}

In principle, the Domestic Violence Act is part of protection measures to establish a happy and prosperous family whose rules and concept aim to provide legal protection to Victims of Domestic Violence, especially women as stated in Article 1 of Law No. 23 of 2004 concerning the Elimination of Domestic Violence. Such protection must be carried out in an integrated manner, in synergy between the government and society. In addition, each party will provide services to victims of domestic violence in accordance with their respective fields ranging from the police, health workers, social workers, volunteer assistants, spiritual mentors. In addition, Prosecutor's Offices and the Court in prosecuting and making decisions on perpetrators of domestic violence play a vital role in giving a deterrent effect to anticipate the recurrence of domestic violence cases. The presence of society is urgent to accommodate the interests of perpetrators, victims and society in relation to the criminal justice system which is likely to be a criminal factor and less pleasing for all parties.

\section{REFERENCES}

[1] R. Mardjono, Sistem Peradilan Pidana. Jakarta: Pusat Dokumentasi Hukum UI, 1983.

[2] A. Ali, Menguak Teori Hukum (Legal Theory) dan Teori Peradilan (Jurispridence). Jakarta: Kencana Prenada Media Group, 2009.

[3]. Amiruddin and Zainal Asikin, Pengantar Metode Penelitian Hukum. Jakarta: PT. Raja Grafindo Persada, 2004.

[4] ND Mukti Fajar and Yulianto Achmad, Dualisme Penelitian Hukum Normatif dan Empiris. Yogyakarta: Pustaka Pelajar, 2010.

[5] al M. and F. U. Akb, "The Position and Rights of Indigenous People Ammatoa Kajang: a Perspective of Judicial Normative," 2019.

[6] R. Sihite, Perempuan, Kesetaraan, dan Keadilan Suatu Tinjauan Berwawasan Gender. Jakarta: PT RajaGrafindo Persada, 2007.

[7] P. M. Hadjon, Perlindungan Hukum bagi Rakyat. Surabaya: Bina Ilmu, 1987.

[8] S. Mertokusomo, Mengenal Hukum (Suatu Pengantar). Jogyakarta: Jogyakarta, 1991.

[9] S. Soekanto, Pokok-Pokok Sosiologi Hukum. Bandung: Rineka Cipta, 1980.

[10] Ludfi et.al, "Mediasi Penal: Alternatif Penyelesaian Perkara KDRT," J. Huk. Islam, vol. XVIII, 2018.

[11] A. Gosita, Masalah Perlindungan Anak (Kumpulan Karangan). Jakarta: PT. Bhuana Ilmu Populer, 2004. 